\title{
NIEMEYER, SGULLIN AND THE AUSTRALIAN ECONOMISTS
}

\author{
By Alex Millmow \\ University of Ballarat
}

This article revisits the Niemeyer mission to Australia in 1930 and shows how it facilitated the entry of local economists into the art of policy making. Until then the Scullin government had little regard for the worth of academic economists, a view shared by bankers and central bankers alike. With Niemeyer's dogmatic advice considered too draconian by a vacillating government, Australian economists, led by L. F. Giblin and D. B. Copland, were galvanised into providing a more palatable alternative. This advice eventually transformed into the Premiers' Plan which complemented the devaluation and wage cut, both of which had been implemented in January 1931. While the Plan in its entirety was deflationary it was a more equitable and imaginative blueprint than Niemeyer's.

\section{INTRODUCTION}

Sir Otto Niemeyer has a special place, even infamy, in twentieth century Australian history. While the literature has celebrated the political, economic and imperial aspects of the Niemeyer mission to Australia, none have explored the impact of it upon the local economics profession. Accessing new archival sources, this article re-evaluates the Niemeyer mission, showing in particular, how it served as a catalyst for the mobilisation of local economic expertise. The publicity and controversy surrounding the visit, together with the draconian advice that flowed from Niemeyer's lips, gave Australian economists recognition and an opportunity to exercise what would prove a more acceptable approach to Australia's woes. The article proceeds by examining the economic preconditions which led to Scullin accepting the idea of the Bank of England sending a mission to Australia. The article also highlights some progenitors to the Niemeyer mission. Before this, a brief outline on the Australian economics profession and their analytical vision and contribution to economic policy is appropriate. The article concludes by underlining the accidental but positive outcomes that ensued from Niemeyer's visit. 


\section{GRIM FOREBODINGS}

In the history of the Commonwealth, no administration has been more challenged by economic circumstances as confronted the Scullin Government. Scullin took office only days before the Wall Street Crash of October 1929. Yet for all the scale of the undertaking Labor was elected into, many had foreshadowed that the day of reckoning was coming for Australia. During the federal election campaign of 1929, Scullin warned voters that Australia was heading into a horrendous economic situation by incurring an excessive level of foreign debt to finance infrastructure projects at a time when export prices were softening. ${ }^{1}$ Scullin's Jeremiad warnings had a tragic element. As Robertson, his biographer remarked: 'It is often the fate of prophets to be ignored; but it does not always follow that the prophet is destroyed by the calamity he has foreseen. ${ }^{2}$ Scullin's greatest tragedy was that while having an appreciation of the economic problems besetting Australia, he shunned, until too late, the advice of economists.

A survey of the economic conditions prevailing in the late 1920s illustrates the debt-deflation trap which the Australian economy was tumbling into. For eight years in the 1920s, Australia had imports running ahead of exports with the debt servicing costs met from the proceeds of fresh borrowing. While there were institutional checks, the prevailing psychological mood was one of unbridled optimism. In his study of the economic philosophy guiding the Bruce-Page Government, Richmond linked the optimism of 'men, money and markets', to a grand imperial vision. ${ }^{3}$ The loan proceeds financed a huge appetite for imports, which left in turn, the federal government awash with customs duty. The bellwether of success for Bruce's development schemes was judged in terms of per capita income, rather than the aggregative performance of the economy.

The scale of Commonwealth, and even more importantly state government loan undertakings, together with overdrafts, alarmed some in London. Keynes remarked that Australia was 'gravely embarrassed by the fall in the price of their staple exports' and was therefore craven to borrow at 'whatever rate lenders demand of them'. 'While the Commonwealth's trustee status 'silenced tongues and criticisms' of Australia's borrowing excesses, the British Treasury was far from subservient. ${ }^{5}$ It had, for some time, been antagonistic to Australia's assisted migration and land settlement scheme which saw Britain absorb some of the interest bill of the Commonwealth's borrowings. The $£ 34$ million agreement between the states and the Overseas Settlement Office, an agency of the British Government, signed in 1925 was the most outstanding example of this. ${ }^{6}$ British Treasury officials detected, moreover, how Australian politicians seemed more interested in

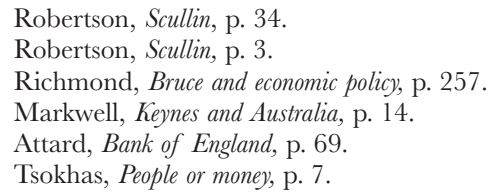


welcoming the financial capital rather than the human capital aspect of the arrangement.

While the states had to take a quota of British migrants, there was no compunction to retain them. Many in fact returned home, but Australia did not have to remit the capital sunk into land settlement or infrastructure. ${ }^{7}$ The Governor of the Bank of England, Montagu Norman would be well aware of the antics by Australian politicians because Commonwealth borrowings during this period had to be embargoed to allow Britain's return to the Gold Standard. ${ }^{8}$ Afterwards, however, Norman facilitated Australian borrowing by offering good terms to deter Australia turning to New York. Australia denied its position as a dependent economy by engaging in a form of 'financial entrepreneurship' playing the London capital market agents off their New York counterparts. ${ }^{9}$

There is general agreement that the depression in Australia was triggered by exogenous factors that compounded the deep-seated internal problems fomenting during the 1920s. The loss in export revenue of some $£ 40$ million, together, with the cessation of borrowing of some $£ 30$ million meant a loss in national income of some 10 per cent in 1930 alone. ${ }^{10}$ With the cessation of capital borrowing ordered by the Bruce Government, servicing Australia's huge overseas loan portfolio would now have to be drawn from local resources.

Melbourne University economist Douglas Copland gave the best contemporaneous account of how Australia's economic difficulties had arisen. He identified four 'danger-spots' or 'weaknesses' in the economy, namely: the rising ratio of interest payments to export revenue; the increasing levels of tariff assistance; the disparity between Australian and foreign price levels and, not least, state and Commonwealth deficit budgets. All these, Copland reasoned, would have necessitated some adjustment for the economy notwithstanding the ongoing deterioration in the global economy. ${ }^{11}$ Interestingly, Copland rejected the argument that there had been extensive economic mismanagement. A dependent economy, he said, was 'only partially master of its own house'; in that sense Australia had been embarrassed by the calamitous fall in export prices. ${ }^{12}$

Where economists had expressed alarm at Australia's insatiable demand for funds and their dispersal into unproductive ventures, it barely registered. This allocation of funds supposedly went with the scientific administration ambitions of the Bruce Government lending a new air of sophistication to policy development. ${ }^{13}$ With Scullin's accession to power, the paradigm of 'development' came to an abrupt end. The Chairman of the Commonwealth Bank Board, Sir Robert Gibson, informed Scullin that budget deficits would no longer be sustained and that he would not issue any more Treasury bills until commitments were given

7 Tsokhas, People or money, p. 16.

8 Tsokhas, Anglo American entente, p. 622.

9 Tsokhas, Anglo American entente, p. 638.

10 Copland, Australia, pp. 644-5.

11 Shann and Copland, Crisis, p. 95.

12 Copland, Australian problem, pp. 638-640.

13 Castles, Scientific economics. 
towards achieving budgetary equilibrium. There was dithering responding to the problem simply because the Scullin Government had been elected on the promise that it would shelter the working man from the economic blizzard. ${ }^{14}$ Shaping a meaningful response to the gathering storm was also hampered by adversarial politics and complicated even further by the federal-state divide. While the Commonwealth and the six states were all regarded as equal partners, it was still an era when citizens looked more to their state capitals than Canberra.

Colin White has argued that the delay or 'policy vacuum' in Australia coming to terms with the twin shocks of falling export prices and cessation of capital inflow, was essentially due to the absence of a 'central economic authority'. ${ }^{15}$ The Federal Treasury's standing within the economy was elevated when the Australian Loans Council was established as a statutory body in 1927. The Treasury acted as the Council's secretariat but its influence over economic policy was still minimal. The Commonwealth Bank Board, in contrast, exercised primary control over monetary policy and exerted a strong voice in the Premiers' Conference regularly held to deliberate upon the disbursement of federal funds.

The Commonwealth Bank was not truly a central bank, partly because the trading banks did not have to keep reserves or share commercial information with it and indeed regarded it as a competitor. The Commonwealth Bank was, therefore, unable to exert control over the exchange rate or even gauge the depth of Australia's external reserves or 'London funds' held by trading banks. Nor did the Bank Board totally possess the expertise that went with the art of central banking. For all his intransigence and ignorance of central bank techniques, Gibson was still the most important individual determining the course of economic policy during the depression. ${ }^{16}$

Gibson and his Board exercised some authority over interest rates, though the more powerful banks could prove recalcitrant. On matters of monetary doctrine, the Bank Board rigorously upheld the stability of the exchange rate and was vigilant about 'monetary credit' abuse. ${ }^{17}$ These decentralised and vague monetary arrangements brought the banks into almost immediate friction with the Scullin Government over the drain of Australia's reserves and cessation of borrowing from London. The fall in the London funds meant that the banks had to restrict, quite properly, their advances. Labor politicians saw this subsequent credit squeeze, however, as deliberate sabotage.

Gibson's problematic relationship with the new government unfolded in one extraordinary scene. Scullin, fazed by the convention of a seven-year term for the Chairman of the Bank Board, wanted to make Gibson's reappointment conditional on the premise that he render an undated resignation letter. When Gibson

14 Scullin at first took a remarkably benign view of unfolding developments. On 21 November 1929 he publicly intoned '....we do not view the future with alarm - our troubles will soon be over. Cited in Anstey, Memoirs, p. 371.

15 White, Mastering risk, p. 190.

16 Giblin Central bank.

17 Melville Transcript, 26. National Library of Australia (hereafter NLA). 
rebuffed the offer, Scullin supinely gave him another seven-year term. ${ }^{18}$ Gibson was reappointed essentially because of the immense psychological reassurance his presence gave to the local and international banking community. Gibson soon showed his mettle by informing Scullin before his departure for an Imperial Conference in London that the Federal Government implement immediate expenditure cuts or face impending bankruptcy with the internal and external loans fast maturing.

\section{THE AUSTRALIAN ECONOMICS PROFESSION IN THE 1930s}

Australian economics in the late 1920s was a fledgling university discipline with only six chairs (Melbourne, Sydney, Hobart, Adelaide, Brisbane and Perth). It was a Cinderella science but the economic challenges facing Australia held promise for the profession. ${ }^{19}$ The economists at Australia's disposal were to prove a remarkable vintage. ${ }^{20}$ Like their British counterparts, Australian politicians had begun to solicit advice from economists. There was something within the nature of the Australian economics profession which lent itself to giving practical advice rather than engaging in theoretical research. Giblin later reflected upon this attribute:

In Australia economists are a particular tribe. Rarely are they nourished by the pure milk of the word. Mostly they have been advisers to governments for many years permanently or intermittently, publicly or privately. Governments do not love them but are inclined to believe honest... They are frequently more practical and realistic than businessmen... They are resented of course by sectional business interests. The word of complaint or abuse is 'academic'; but, in truth, they are the least academic of God's creatures. ${ }^{21}$

In like spirit, L. G. Melville, reviewing the events of 1931, recalled that 'Essentially we were all pragmatists dealing with applied economics, applied to practical problems that were developing very rapidly. ${ }^{, 22}$

In terms of ranking, Melbourne was prominent because it was the home of the Economic Society of Australia and New Zealand. The Society was, in part, sponsored by the banking and business community and brought businessmen, economists and public servants under the one roof. Considered politically safe, Copland was regarded as 'the proper custodian and expander... of absolute and unbending economic laws. ${ }^{, 23}$ Copland set out to secure the bridge between town and gown by offering a degree in commerce. It was rapturously received. ${ }^{24}$

18 Obituary of Sir Robert Gibson in The Scotsman (5 January 1934), and obituary of Sir Robert Gibson in The Argus (2 January 1934), Gibson Papers. Mss. 10823, Latrobe Library.

19 Bourke Social scientists, p. 67.

20 Butlin, Hundredth record, p. 509.

21 Hytten, Giblin as an economist, p. 154

22 Melville, Transcript NLA 9.

23 Spierings, Exacting, p. 133.

24 Selleck, The shop, p. 693. 
At Sydney, Richard Mills held the chair and was intent upon building a factory of local economic expertise. Despite Melbourne's prominence, Sydney would boast that it possessed Australia's only ensemble of professionally-trained economists. $^{25}$

Copland entered into the debate over monetary policy when Australia's financial link with London came under pressure with the calamitous fall in export prices during 1929-30. Under the rules of the game, Australia could only recover external balance by a severe deflation brought about by a direct reduction in bank credit consistent with her dwindling London funds. Inspired by Keynes' Tract, Copland reasoned that internal price stability should rank before exchange rate stability and that the transmission of large movements in credit, via the external account, be avoided for the sake of economic stability. In a lecture to the Economic Society in June 1930 Copland provoked controversy by urging a break with sterling. Copland set out to enlighten high and financial opinion away from the Anglo-Saxon fetish that a unit of money, in this case the Australian pound, become a variable unit and not something fixed in terms of gold. It was to prove a long struggle.

Before Copland's lecture upon monetary policy Australian high politics had, as mentioned, established the precedent of calling upon the 'experts' to advise upon aspects of public policy. It was the Bruce Government's appointment of the Brigden Committee in 1928, to review the Australian tariff that first made the name of Australian economics. In the foreword to the Report of the Tariff Committee Bruce hailed it as 'a free gift to the Australian people'. This was a reference not just to the Report's clarity and lucidity but also how economists laboured without compensation. ${ }^{26}$ They did not labour in vain, however.

That effort mirrored comparable developments in Britain where extra-parliamentary economic expertise, in the guise of the Economic Advisory Committee, was pursued with some vigour. ${ }^{27}$ Bruce's 'eyes and ears' in London, R. G. Casey, the liaison officer with the Foreign Office, wrote of the rising power of economics: 'Economics was beginning to show signs of asserting itself' and 'being recognised as the sharp and effective tool of those in power' ${ }^{28}$

Calling upon a repository of economic wisdom was also in the new-found spirit of 'scientific administration' or 'salvation through science'. ${ }^{29}$ By 1929 Bruce had a Bureau of Economic Research on the statute books. ${ }^{30}$ Bruce's rapture with economics and economists, however, was at odds with his countrymen's dislike of scientific economics. ${ }^{31}$ In like regard, the Labor Party attributed the escalation in unemployment between 1927 and 1929 to the high volume of both imports and immigration. The Scullin Government subsequently decided to postpone assisted

25 Butlin, A Fraternal farewell, p. 102.

26 Davidson, Brigden, Vernon, pp. 146-7.

27 Howson and Winch, Economic advisory board.

28 Hudson and North, My dear PM, p. 502.

29 Howson and Winch, Economic advisory board, p. 159.

30 Castles, Scientific economics, pp. 26-28.

31 Hancock, Australia, p. 86. 
migration and abolish the Development and Migration Commission. ${ }^{32}$ This action ruffled British feathers, especially since it was an undertaking managed jointly with Whitehall.

The idea of a Bureau of Economic Research, too, was abandoned. Labor had already voted against the proposal whilst in opposition. In complete ignorance of what economists said about the tariff, Arthur Blakely accused them of being 'brought up in schools of economic thought and ideas quite foreign to conditions prevalent in Australia'. 'The economist' he continued 'is academic, conservative and anti-working class and lives in a world of his own' ${ }^{33}$ Scullin, too, took a swipe at the ostensibly 'academic' orientation of the people who would staff the Bureau: 'The textbooks teem with the opinions of the so-called leading economists of the world on the subject of free trade and protection... [The people] are not concerned with the opinions of learned persons who talk about a wonderful flow of trade through uninterrupted channels, ${ }^{34}$

\section{A PREGURSOR TO NIEMEYER}

In the same year economists reported upon the tariff, Australia as Gilbert put it, 'invited trouble' by having an official British Economic Mission come out and assess the condition of the Australian economy. ${ }^{35}$ Bruce had hoped to use the Mission to alleviate growing concern in the City over Australia's rate of borrowing. ${ }^{36}$ However, the Mission in a reprise on Whitehall opinion, criticised Australia's new protectionism, especially, the practice of wage indexation. It encouraged the Bruce Government to square the circle by attempting industrial relations reform. ${ }^{37}$

The concern about Australian cost levels drew one member of the British Economic Mission to note: 'The nub of the problem had been identified as the great and growing costs of production, for which growing tariffs and correspondingly growing costs of living and of labour are primarily responsible, and which are further enhanced by the unremunerative expenditures of borrowed money. ${ }^{38}$

Australian economists were heartened by the Mission since it assailed the intrusive nature of government intervention within the economy, particularly the link between tariffs and wage arbitration. The Mission guardedly found Australia's economy to be fundamentally sound in that she could meet existing debts and provide for local services. ${ }^{39}$ It concluded, however, that Australia 'had been

34 Castles, Scientific economics p. 28.

35 Gilbert, Loans council, p. 114.

36 Roe, Australia, Britain, p. 126.

37 Cumpston, Lord Bruce, p. 86.

38 Malcolm, Australian Loan, pp. 19-20.

39 Gilbert, Loans Council, pp. 114-15. 
mortgaging the future too deeply and would do well to restrict her expenditure of borrowed money for development'. ${ }^{40}$ It echoed, therefore, the British Treasury concerns about the end-uses of borrowed capital, particularly the flagrant abuse of the land settlement scheme. The general impression formed in London from the report, as Casey relayed to Bruce, was that '...they do not think we have been very clever with our nation planning in the past'. ${ }^{41}$ Some correction, it was true, was in the offing once the Australian authorities came to an orderly arrangement with their financial agreement over loan raisings, but the damage had been done. Neutralising to some extent, the impact of the Mission's findings, especially on protection, was the Brigden Committee's findings, which gave qualified support to the Australian tariff.

Appreciative of the economic problems confronting them, Scullin and Theodore asked the London-based Australian businessman, W. S. Robinson, to make secret representations to the Bank of England about deferring an impending loan maturing. Robinson was given short shrift by 'our old friend' Sir Ernest Harvey: 'Please don't ask for that which perforce I must refuse. ${ }^{, 42}$ Giblin felt the Bank of England's action was 'very cold. Its attitude was rigid...Australia must solve its own trouble for itself ${ }^{43}$ Australia, by dint of some years of negative, but for the most part, accurate reporting, had become the 'bad boy of the Commonwealth' and an example to be made of. ${ }^{44}$

\section{THE NIEMEYER MISSION}

Local economists were probably taken as much by surprise as most Labor Party officials were when informed that the Bank of England was despatching Sir Otto Niemeyer to undertake an evaluation of the Australian economy's finances. While there has been some controversy about who invited Niemeyer out, Sir Robert Gibson told a leading Melbourne stockbroker that it was he who had arranged the visit. ${ }^{45}$ In the literature Scullin is often portrayed as having been somewhat inveigled into accepting a visit from Bank of England officials. ${ }^{46}$ This is not so. Given Scullin's unilateral decision concerning Gibson's reappointment, accepting a visitor from Threadneedle Street gave the financial community further psycho-

40 The Economist, 16 November 1929.

41 Hudson and North, My Dear PM, p. 462.

42 Robinson, Remember rightly, p. 147.

43 DB Murdoch, Secretary to the Commonwealth Bank Board, later told Giblin he was astounded at Sir Ernest Harvey's refusal to grant emergency financial assistance to the Scullin government given that he had been 'a good friend' to Australia earlier (DB Murdoch to LF Giblin, 8 April 1947, Reserve Bank of Australia: GLG-51-5).

44 Giblin, Central Bank, p. 81.

45 J.B. Were, Ricketson diary, 2 June 1930. One of the conditions of Niemeyer's visit was that Sir Robert Gibson was to have the first interview with him and be allowed constant access to him. J.B.Were, Ricketson Diary, 25 June 1930.

46 Attard, Bank of England. 
logical assurance. Scullin entertained the possibility that the Bank of England might accommodate Australia with a loan to cover the short term overdrafts to English banks in London if his government followed Niemeyer's advice. ${ }^{47}$

It could be said that the local nucleus of economists was also grateful for Niemeyer's visit, since it added a much-needed degree of gravitas to the problems at hand. Giblin sent Niemeyer a note of welcome on behalf of his colleagues. ${ }^{48}$ A. C. Davidson, the economically enlightened General Manager of the Bank of New South Wales, hailed Niemeyer's arrival as 'the first occasion in half a century that economic talks may be brought home forcibly to the people of Australia and those who rule over them'. ${ }^{49}$

When Niemeyer, his economic adviser Professor T. E. Gregory of the London School of Economics, and an Australian-born assistant from the Bank of England, Richard Kershaw, arrived in July 1930, they were unaware of the political storm they were to cause. For Niemeyer would bring the house of English orthodox economics down upon Australia's head. It would materialise in him attacking the 'Ark of the Covenant', Australia's living standards. ${ }^{50}$ At one point, towards the end of his sojourn, Niemeyer actually put out a public statement telling of the circumstances that led to his invitation to Australia. ${ }^{51} \mathrm{He}$ was here, palpably at the invitation of the Commonwealth Government, following a suggestion by the Bank of England that an independent study of Australia's finances be undertaken.

Niemeyer's brief was to diagnose the nature of the Commonwealth's economic problems and put forward advice as to its resolution. It afforded London another opportunity to wage a critique of Australia's pattern of economic development. ${ }^{52}$ Moreover, Niemeyer entertained a secret agenda, namely to steel the resistance among local trading banks to Theodore's Central Reserve Bank legislation - a development the Bank of England looked upon with some trepidation. ${ }^{53}$

Niemeyer was bombarded by correspondence offering advice on what was ailing the Australian economy. Much of the correspondence pinned the blame on Australia's cost structure upon the tariff-arbitration system lending support to what Niemeyer had in mind to say. The South Australian Labor leader, R. L. Butler, informed Niemeyer that Australia's problems had all to do with the political patronage of public works. This seemingly registered with Niemeyer because it is one of the few unsolicited letters to which he made more than a cursory reply. Butler wrote about the possibility of privatising the national assets that Australia had spent millions in developing. To correct Australia's trade account, Butler raised the possibility of manufacturing exports. ${ }^{54}$ Niemeyer agreed that manufacturing exports were a possibility but he had 'some doubt' whether

Schedvin, Depression, pp. 180-182.

L.F. Giblin to O.Niemeyer, n.d, Giblin Papers Mss. 366 NLA.

A.C. Davidson to O. Niemeyer, n.d. Bank of England (hereafter BE): OV9/288.

'Sir Otto Niemeyer in Australia', Nation and Athenaeum, 17 January 1931.

Sydney Morning Herald, 17 October 1930.

Roe, Australia, Britain, p. 148.

Attard, Bank of England.

R.L. Butler to Niemeyer, 27 September 1930. BE: OV9/288/43. 
this would be achieved because the margin between the wages of England's industrial workers in the export industries and the Australian equivalent was immense. ${ }^{55}$ Butler was, as we shall see, to play a significant part in the unfolding drama.

As an old Treasury man, Niemeyer might have been privy to a report written by Skevington who had visited Australia the year before and made critical remarks about Australians' self-belief in the great potential of their country. He found 'their ignorance of economics... pathetic' ${ }^{56}$ For his own part, Niemeyer would also be only articulating what he had already written upon for the Bank of England's edification. ${ }^{57}$

The high point of Niemeyer's fact-finding tour was his infamous address at the Melbourne Conference of Commonwealth and State Leaders where he told his audience that the 'cold facts must be faced'. His diagnosis of Australia's predicament was blunt, if not predictable: 'In short, Australia is off budget equilibrium, off exchange equilibrium, and faced by considerable unfunded and maturing debts both internally and externally, in addition to which she has on her hands a very large program of loan works for which no financial provision has been made'. ${ }^{58}$ Niemeyer warned Australia had two years 'to get its house in order' before a tranche of external debt matured in 1932. Niemeyer's advice at the Melbourne Conference was politely listened to and seemingly consented to in resolution after resolution. However, the peculiarity of Australia's political and institutional arrangements, especially the federal structure of governance, deprived Niemeyer of having a single point on which he could concentrate his pressure.

While in favour of Niemeyer's resolutions the states resented having to make greater proportionate expenditure cuts than the Commonwealth. ${ }^{59}$ The Scullin Government, while agreeing that budgets had to be pruned, exercised a policy of Micawberism. Niemeyer found the Australians' resistance to buckling under disconcerting, believing they were far too optimistic about their country's future prospects.

Meanwhile, populist politicians like Jack Lang and Billy Hughes penned literature decrying the Niemeyer diagnosis and therapy. What irritated Niemeyer most was the boundless optimism of his hosts and the thought there must exist an easier way out of their predicament. Niemeyer vented his frustration in a missive to Norman: 'They are occupied half the time saying that the present difficulties are not their fault but somebody else's - either Bruce's or the London Markets or the general perverseness of the world and the other half in trying to find ingenious ways by which somebody else should help them out. ${ }^{60}$ When Niemeyer read in

Niemeyer to Butler, 2 August 1930, BE: OV9/288/43.

Roe, Australia, Britain, p. 136.

Attard, Bank of England, p. 81.

Shann and Copland, Crisis, p. 21.

Tsokhas, Sir Otto Niemeyer, p. 20.

60 Niemeyer to M. Norman, 1 September 1930, BE: G1/291. 
local papers that the British Government was still considering a proposal guaranteeing loans for further land settlement he cabled the Deputy Governor at the Bank of England, Sir Ernest Harvey:

Can you tell me whether there is any truth in this, as rumours have bad effect on these optimists? Australia is a poor country, probably over-populated with a higher percentage unemployed than U.K. Settlement hitherto has been very costly and unsuccessful; future development at present seems to me insane. ${ }^{61}$

Niemeyer was horrified to learn, too, of the activities of Scullin in London. Apart from seeking relief for Australia's war debts, Scullin had approached the Bank of England about getting approval, or at least a vote of confidence for his stand against a Caucus proposal to extend the due date of some maturing debt. ${ }^{62}$ Despite Niemeyer's warning to Scullin that London would not give him a warm reception, the Australian Prime Minister asked whether the Bank would provide the money to enable the Commonwealth to pay off some five million pounds of maturing Treasury Bonds. ${ }^{63}$ Harvey, who had visited Australia in 1927 to advise upon establishing a central bank, declined both requests; the second because it was unheard of and the first because the Scullin Government had, so far, not moved to implement Niemeyer's advice. Earlier, the Bank of England, at Niemeyer's suggestion, was prepared to help finance the maturing of Treasury Bonds in late 1930, but only if the Scullin Government implemented the Melbourne resolutions ${ }^{64}$ Sir Richard Hopkins of the British Treasury annotated the report of the interview between Scullin and Harvey with the comment: 'It is a bad business. ${ }^{65}$

In his diary Niemeyer was unflattering toward his hosts and quite unimpressed with federal politicians, civil servants, bankers and other professionals. ${ }^{66}$ Niemeyer confided to the official representative of the British Government E. T. Crutchley, that 'He had had a lot to do with bankrupt countries but have never seen one more utterly impotent to help itself ${ }^{67}$

Even Gibson 'staggered' Niemeyer by prophesising - correctly as it turned out - that Britain would go off the Gold Standard within six months. ${ }^{68}$ Apart from that indiscretion Niemeyer told Lady Gibson that her husband was 'the most

61 Niemeyer to E. Harvey cablegram, 14 August 1930, Public Record Office (hereafter PRO): T161/396/11935/02.

62 Tsokhas, 'Coldly received', p. 21.

63 Tsokhas, Sir Otto Niemeyer, p. 25.

64 Scullin's extraordinary requests might be understood by Theodore having received a letter from J.M. Myers of The Financial Times, informing him that the Bank of England might give Australia direct financial assistance as a result of the large gold shipment which had proved extremely useful to the Bank in its dealings (J.M. Myers to E.G. Theodore, 6 August 1930, Theodore Papers, NLA Mss.7222). Casey had earlier complained to Bruce that Myers' paper was chiefly responsible for fomenting negative sentiment about Australia's finances.

65 Copy of interview with Scullin and Harvey, PRO: T161/396/11935/02.

66 Love, Diary.

67 E.T. Crutchley Diary, 14 August 1930, NLA.

68 Recollections of Sir Robert Gibson by Sir Harold Clapp' Latrobe Library, Gibson Papers, Mss. 10823. 
outstanding figure of all those I met', ${ }^{69}$ and that 'Australia could never repay Sir Robert Gibson in thousands what he had saved the country in millions'. ${ }^{70}$ Niemeyer was also impressed by Leslie Melville, particularly his espousal of deflationist economics that he recommended him to Gibson as the Commonwealth Bank's first economic adviser. ${ }^{71}$ Melville took up that appointment in March 1931. ${ }^{72}$

Niemeyer's unflattering appraisal of Australia's politicians sprang not just from his highly developed sense of personal superciliousness but also British Treasury's concerns about land settlement schemes. It also sprang from Montagu Norman's advice to distrust 'all Australian Governments and Ministers'. ${ }^{73}$ The background to this, as Casey informed Bruce, was that Norman had already found his advice unheeded about setting an issue price on Australian loans floated in London. ${ }^{74}$

\section{ENTER THE ECONOMISTS: MELBOURNE SCHOOL VERSUS MELBOURNE AGREEMENT}

As mentioned, Copland's less austere middle monetary policy was circulating before Niemeyer gave his Melbourne address. It entailed real wage cuts in tandem with devaluation. After receiving a copy of Copland's July lecture, Keynes told him that he had 'considerable sympathy with line' being taking. ${ }^{75}$ Growing opposition to Niemeyer prescription gave the Copland approach wider currency. Melbourne stockbroker Edward Dyason told the Acting-Treasurer, Joe Lyons, that Niemeyer's advice was 'inimical to the national interest and dangerous to the social fabric'. ${ }^{76}$ Giblin added his weight, telling his old friend Lyons that if deflationary policies were carried out Australia was headed for a 'bad smash with the chance of revolution and chaos'. ${ }^{77}$ Lyons consequently commissioned Copland, Giblin and Dyason to frame an alternative to Niemeyer. Copland later identified this as the first instance where economists were called in to give official advice upon how to combat the economic crisis. They had, in fact, already undertaken a series of meetings to ascertain the loss in national income and the means to restore it. Copland later claimed that the basis of what would become the Premiers' Plan was first outlined by economists at an ANZAAS meeting held in

69 Niemeyer to Lady Gibson, 1 January 1934. Latrobe library, Gibson Papers, Mss. 10823.

70 Unfinished Manuscript by Margaret Gibson on her father, Sir Robert Gibson, p. 50. Latrobe Library Gibson Papers, Mss. 10823.

71 E. Shann to W. J. Young, 17 February 1932. Bank of New South Wales archives (hereafter BNSW): A53/409.

72 R. Kershaw to L.F Giblin, 29 May 1947, BE:G1/288.

73 Norman to Niemeyer, 22 August 1930, BE:G1/291.

74 Hudson and North, My dear PM, 440-441.

75 Keynes to Copland 20 August 1930, Keynes Papers King's College (hereafter KPKG).

76 E.C. Dyason to J.A. Lyons, n.d; Lyons Papers, NLA,

77 Cited in Hart, f.A. Lyons: A Political Biography, p. 67. 
Brisbane in May 1930. Initially the economists, especially Melville, were coy about involving themselves in public affairs. Melville was worried that 'interference by university economists in public affairs is a delicate matter because of the strong financial assistance rendered to universities by Australian governments'. ${ }^{78}$ Copland eschewed this reservation. The first step was to quantify the loss in real income and then ensure that the loss be fairly distributed across the community. This was made the first condition of recovery. Real wages had to fall and indexation cease. As the Arbitration Court's expert witness in the 1930 national wage case, Copland took up the challenge with relish.

There was no record in Niemeyer's diary or papers of having met or corresponded with Copland. Giblin, in his recollections to Walker, did report however frequent clashing with Niemeyer, especially over protection. ${ }^{79}$ For his part, Niemeyer felt Giblin was 'pretty disappointing ${ }^{90}{ }^{80}$ Gregory did see Copland and Giblin, a day before Niemeyer's keynote address before the Melbourne Conference. Gregory cryptically reported back that the conversation gravitated around two points, the exchange rate and real wage cuts. Gregory posed the question to both academics of what was Australia's optimal path out of its depression, namely, deflation or devaluation. He found Copland more careful in his qualifying analysis than Giblin, but also more likely to be 'inflationist', by that, urging a rise in the price level via devaluation. In the record of that interview there is no mention of Copland's expedient, articulated in his 1930 Economic Fournal article, of how a money wage cut would deliver a real wage cut. Giblin and Copland spoke rather about how devaluation would suppress imports, and more importantly, give a stimulus to primary and secondary industries coupled with compensating reductions in the tariff. Gregory insisted that primary producers would not escape a raft of rising costs due to the import bill increasing. The two Melbourne economists confided that they saw unemployment ballooning to 25 per cent. Significantly, Copland mooted the idea of 'a general scaling down' of interest rates, but Gregory thought it was not 'a considered point of view of what was possible, on his part'. ${ }^{81}$

Apart from this interview and his Fisher Lecture, Gregory kept well in the background during his visit. His one contribution to the media, as events unfolded, proved an interesting one. He refuted the Laborist argument then extant, that a reduction in interest rates must precede wage cuts: 'If we look at it strictly as an economic proposition, both rising rates of interest and the growth of unemployment are evidence of maladministration in Australian economic affairs, and, from a strictly economic point of view, you cannot assert that it is unjust that interest rates remain high while wages fall if the high rate of interest is unnecessary to attract capital and a lower rate is necessary to attract a demand

78 Melville to Davidson, 25 November 1929, BNSW: GM 302/374.

79 Cain, Australian economists, p. 6.

80 Love, Niemeyer's diary, p. 273.

81 Notes on Conversation with Professors Giblin and Copland at Melbourne, 19 July 1930, BE: OV9/242. 
for labour. ${ }^{82}$ The deadlock would only be broken in January 1931 when the Arbitration Court ordered a 10 per cent wage cut. Copland praised the decision as a first step towards economic readjustment. ${ }^{83}$ Until then, the Melbourne school issued a plan for economic readjustment encompassing both devaluation and the monetising of budget deficits with Treasury bills. It was a middle way between inflation and deflation. It would allow the internal price level to return to predepression levels. Like Davidson, Melville was aghast at the Melbourne price stabilisation proposals while Shann, less opposed, identified the practical difficulties of implementing it with an obstructionist Commonwealth Bank. There were fears too, that it gave support to the Labor Party's plans for a centralised and politically controlled central bank. Certainly the Melbourne school gave some support to the notion of price stabilisation in a bid to counter the external shocks which, if left untreated, spelt considerable deflation.

As hopes of implementing the Melbourne Agreement receded Niemeyer wrote to Hopkins: 'This is an odd country, full of odd people and odder theories. ${ }^{84}$ Meanwhile Melville had, at Niemeyer's urging, gone on the attack against the Melbourne school, which was then considering Theodore's idea of price stabilisation achieved by a fiduciary issue. . 'Melbourne brains' so antagonised Niemeyer that he cabled Harvey about 'much wild talk in Caucus about expanding credits and tots of brandy inflation has supporters in Theodore and Melbourne economists' ${ }^{86}$ Niemeyer encouraged Melville to keep up the fight against 'Copland and Co' and their 'dangerous nonsense', part of which was about devaluation. ${ }^{87}$ Niemeyer, along with the English-owned Melbourne banks, saw little logic in Australia having to pay more to service its debt or imports. It was held that primary producers would also extract little benefit because of the higher costs caused by the devaluation. In a dig at the Melbourne economists, Niemeyer remarked how "curious a commentary it is on human psychology that the same people talk in one breath of the boundless potentialities of Australia and in the next of the necessity of writing down those potentialities by 20 per cent ${ }^{98}{ }^{88} \mathrm{~A}$ heartened Melville replied that the camp of the stabilisationists was technically reduced to monetising the deficits directly since the trading banks would not expedite it by purchasing government securities and, if that were to happen, there would be a flight from currency. He sought Niemeyer's opinion about Giblin's contention, reported in the press ${ }^{89}$ that 'our best efforts at balancing the budget were hopeless at the present time. ${ }^{90}$ Niemeyer felt Giblin's pessimism about balancing the budget was symbolic of a 'quitter' mentality he had found among

85 The Adelaide Advertiser, 31 October 1930.

86 Niemeyer to Sir E. Harvey cablegram, 3 November 1930, BE: GI/291.

87 Niemeyer to Melville, 1 November 1930, BE: OV9/289.

88 Niemeyer to Melville, 1 November 1930, BE: OV9/289.

89 The Argus, 30 October 1930.

90 Melville to Niemeyer, 8 November 1930, BE OV9/289. 
his hosts. Niemeyer's reply to Melville, a few days before he set sail for England, rounded on Giblin and Copland's 'hopelessly academic' measures as meaning only one thing - inflation: 'The fundamental fallacy of course is the common Australian assumption that it is the business of the banks in general and the Commonwealth Bank in particular to provide capital in the strict sense of the word. The provision of capital is, of course, no part of the functions of any bank. ${ }^{91}$ Niemeyer remarked that there had already been some 'considerable inflation' in the financing of deficits; he speculated also where Australia would draw upon the resources to balance forthcoming budgets or finance public works.

Niemeyer knew that the Melbourne Agreement would be in technical limbo until the outcome of the NSW state election was known. A victory for the conservative leader, T. R. Bavin, would mean that the process of budget balancing in the strongest state in the Commonwealth could proceed and if the Commonwealth Government followed, a loan sponsored by the Bank of England might then be in prospect. Unfortunately, Bavin used the Niemeyer report as the basis of his campaign, giving the unfortunate impression that he was advocating economy and retrenchment at the dictate of London. ${ }^{92}$ Lang, to Niemeyer's horror, mounted his entire electoral campaign opposing the Melbourne Agreement, arguing instead for some form of repudiation. Victory for Lang would therefore be a severe blow to the Niemeyer plan and, as Norman told Hopkins, 'the game would be up' ${ }^{93}$ When Lang won the election, Niemeyer judged that a London issue would 'now be out of the question'94

Even on the day of departure, Niemeyer still strove to expunge the inveterate optimism of his hosts, remarking to journalists that 'there was not enough pessimism around'. ${ }^{95}$ While he left Australia 'to stew in her own juice', Niemeyer had enjoyed the celebrity, or infamy, his sojourn had provoked, telling the Governor of the Commonwealth Bank, E. R. Riddle, that he hated 'being out of the row'. Niemeyer's departure, however, made it easier for Melville to seek a compromise with the Melbourne economists in putting their signatures to a workable plan. In late November the economists reconvened in Melbourne for a two-day meeting. There they agreed that there must be immediate cutbacks to government spending. The 25 per cent loss in national income was being compounded by a loss in business confidence which, in turn, was due to lack of policy action by the authorities. More interestingly, Copland and Giblin dropped the idea of price stabilisation because they lacked the requisite degree of precision in monetary targeting to restore prices to 1929 levels. J. B. Brigden also noted that the scheme diverted attention away from the imperatives of wage cuts and reducing government expenditure. ${ }^{97}$ The economists issued another memorandum in January

91 Niemeyer to Melville, 13 November 1930, BE OV9/289.

92 'Sir Otto Niemeyer in Australia', Nation and Athenaeum, 17 January 1931.

93 Norman to Sir P. Hopkins, 23/10/ 1930, BE: G1/291.

94 Cited in Attard, Financial diplomacy, p. 123.

95 Goodwin, The Image, pp. 230-1.

96 Niemeyer to E.R. Riddle, 24/12/1930, BE: OV9/289.

97 Notes on monetary policy, 5 December 1930 Brigden Papers, NLA. 
1931. Apart from again insisting upon wage cuts and restoring budgetary balance, the economists now wanted a commensurate reduction in rentier income by scaling down interest rates. The latter clause must have caused Melville and Shann some unease but eight economists signed the memorandum. ${ }^{98}$ In that same month Copland took Theodore's fiduciary issue to task. ${ }^{99}$ January 1931, in fact, was a critical month with economists playing a major part first in forcing a wage cut to be imposed nationally and then delivering, through Davidson at the Wales a 30 per cent devaluation. Copland, Shann and Melville persuaded Davidson to bend to market realities and overthrow the carded rate. ${ }^{100}$ The last obstacle in Australia's economic rehabilitation was to address the matter of public sector deficits.

While many could foresee a looming financial crisis, some saw it as doing a power of good. Crutchley reported that "the Commonwealth Bank felt, as did other competitive authorities, that a "crash" so long as it is internal in immediate effect, was not only unavoidable but should be expected as the only way of forcing the Governments and the public to face facts and accept the hardships of reconstruction'. ${ }^{101}$ Theodore was of the same inclination, wanting a crisis to force the Commonwealth Bank to bend to his will. When informed of Labor's embrace of the Theodore plan Niemeyer told the Governor of NSW, Sir Philip Game: 'I am afraid...things have not got much better, as the little wanderer [Scullin] seems to have gone over almost completely to the illusionist. ${ }^{102}$ That expedient faltered in the Senate resulting in further deadlock between the Commonwealth and states. It was the South Australian Premier Butler's casting vote upon the Loans Council that broke the impasse. The establishment of the Copland Committee comprised of economists and Treasury officials came forward with a homespun economic plan. When Scullin succumbed to what later became known as the Premiers' Plan, Niemeyer felt vindicated: 'I am still optimistic to think if he [Scullin] had done this last summer, as he was pressed to do, he would not only have found the task a much simpler one but would by this time have seen Australia on the upgrade. It is really extraordinary how politicians... fail to grasp the momentum with which economic diseases spread if they are not nipped in the bud' ${ }^{103}$ When Niemeyer left Australia he cabled Montagu Norman: 'We have given them a concrete plan to pull on and sooner or later even those who now hold back will follow it'. ${ }^{104}$ Norman agreed: '.. we have shown [the] Premiers a reasonable way of avoiding bankruptcy ${ }^{1}{ }^{105}$ Later a placatory missive from Claude Reading, a member of the Commonwealth Bank Board, played upon Niemeyer's vanity, assuring him that

98 Copland to Shann, 8 January 1931, UMA FECC, Box 10.

99 'Creating Credit: its dangers and limitations', Sydney Morning Herald, 30 January 1931.

100 Holder, History of Bank of NSW, pp. 680-688.

101 E.T. Crutchley to the Under Secretary of State, Dominions Office, 2 April 1931, PRO: T160/ $807 / 11935 / 1$.

102 Niemeyer to Sir P. Game, 24 February 1931, BE OV9/289.

103 Niemeyer to Game, 21 July 1931, BE OV9/289.

104 Niemeyer to Norman, 8 November 1930, BE: G1/291.

105 Norman to Niemeyer, 6 November 1930, BE G1/291. 
the subsequent Premiers' Plan was 'in effect merely going back to everything you said when you were here and adopting the remedies which you included would be necessary'. ${ }^{106}$ Forty years later this delusion continued when an obituary for Niemeyer appeared in The Times stating that 'the Australian people took his diagnosis and his suggested cures in good part'. ${ }^{107}$

\section{RETROSPEGT}

The Niemeyer mission provided local economists with an excellent opportunity to present a fairer, homespun solution to Australia's economic problems. This was no mean achievement since the Labor Party up till then had shunned the advice of economists. ${ }^{108}$ The degree of subtlety and nuance required to negotiate through the crisis could only come from economists with an unerringly common touch. They had to be able to tell parables to explain abstruse economics to ordinary folk to generate the consensus for the measures needed. Giblin would later claim that the solution of Australian economists to their country's predicament was quite distinct from the Niemeyer blueprint which he believed was unrelentingly harsh. ${ }^{109}$ It was, of course, Niemeyer's method of application of remedial policies, together with his air of superiority that proved mindlessly insensitive to political realities that earned him lasting opprobrium. As R. W. Dalton, the senior British trade representative noted: 'Niemeyer was not the success he might have been; he lost his head a bit, was tactless and did some very stupid things'. ${ }^{110}$ Niemeyer had forsaken Keynes' advice that with Australia's export prices already depressed it was 'not a time to choose for pressing her too hard'. ${ }^{111}$ Even Niemeyer's strongest supporter, Sir Robert Gibson, chided him for his pessimism and for not giving the Australian people enough credit to pull through. ${ }^{112}$

Of course, it may well have been that Niemeyer was deliberately painting a gloomy picture to force Australians to take notice - a point Copland and Gibson felt quite necessary in the circumstances. ${ }^{113}$ On that score, Robinson later reported to Theodore that all the Bank of England had really wanted from Australian authorities was a clear-cut policy that the country would balance its budget in four or five years and that there would be no recourse to external loans in the meantime. If Australia subscribed to that, the Bank would do its utmost to help the Commonwealth. This did not assuage the Melbourne economist, Gordon Wood, who fumed years later: 'The resentment of the Niemeyer mission goes

106 Tsokhas, Sir Otto Niemeyer, p. 30.

107 Cited in Mandle, Going it alone, p. 97.

108 Castles, Scientific economics, p. 32.

109 Giblin, Central Bank, p. 84.

110 Attard, Bank of England, p. 82.

111 Keynes, Collected works vol. 20 pp. 381-2.

112 Newspaper accounts on Gibson's obituary, Gibson Papers Mss. 10823, Latrobe Library.

113 Copland to Keynes, 9/10/1930, UMA FECC, Box 10. 
deeper than perhaps you have been led to expect. The personnel were unfortunate, the job was badly handled and the general effect was almost disastrous, despite the necessity for telling the Scullin Government the true facts of the case'. ${ }^{11}$

Two years later after accepting Keynes' invitation to give the 1933 Marshall Lectures, Copland took delight at the sharp criticism by Cambridge economists of Niemeyer's style and therapy. ${ }^{115}$ Poignantly, his lecture series was upon how Australia's brand of unique economic policies and institutions helped extricate the nation from depression. ${ }^{116}$ When published, they drew the attention of Montagu Norman. In a confidential, never disclosed review, Norman believed that Copland was about ' 90 per cent right' in claiming that the remedies applied by Australian economists were suitable to her economic situation and national character. ${ }^{117}$ Acclamation from afar had come at last and from high authority.

\section{REFERENCES}

Anstey, F. (1979) Memoirs of the Scullin Labor government. Historical Studies, 18, 368-392.

Attard, B. (1992) The Bank of England and the origins of the Niemeyer mission 1921-30. Australian Economic History Review, 32, 66-83.

Attard, B. (2000) Financial diplomacy. In: C. Bridge, and B. Attard, eds. Between Empire and Nation: Australia's External Relations from Federation to the Second World War (Kew: Australian Scholarly Publishing).

Bourke, H. (1988) Social scientists as intellectuals: from the First World War to the Depression. In: B. Head, and J. Walter, eds. Intellectual Movements and Australian Society. (Melbourne: Oxford University Press).

Butlin, S. J. (1966) The hundredth record. Economic Record, 42, 508-514.

Butlin, N. G. (1978) A fraternal farewell: tribute to S.J. Butlin. Australian Economic History Review, 18, 99-118.

Cain, N. (1974) The economists and Australian population strategy in the Twenties. Australian fournal of Politics and History, 20, 346-359.

Cain, N. (1983) Recovery policy in Australia 1930-3: certain native wisdom. Australian Economic History Review, 23, 193-218.

Cain, N. (1987) The Australian economists and controversy over depression policy, 1930-early 1931, Working Paper in Economic History, no. 79. (Canberra: Australian National University).

Castles, I. (1997) Scientific economics in Australia 1927-31. Academy of Social Sciences Neresletter, 16 (4), 26-32.

Copland, D. B. (1930) The Australian problem. Economic Fournal, 40, 638-649.

Copland, D. B. (1930) The restoration of economic equilibrium. Economic Record, 5, 170-187.

Copland, D. B. (1934) Australia and the World Crisis. (Cambridge: Cambridge University Press).

Cornish, S. (1993) Sir Lesley Melville: an Interview Unpublished manuscript. Department of Economic History, Australian National University.

Cumpston, I. M. (1989) Lord Bruce of Melbourne (Melbourne: Cheshire).

Davidson, F. G. (1977) Brigden, Vernon Rattigan Jackson. In: J. Nieuwenhuysen, and P. Drake, eds. Australian Economic Policy. (Melbourne: Melbourne University Press).

Giblin, L. F. (1951) The Growth of a Central Bank. (Melbourne: Melbourne University Press).

114 G.L. Wood to W.S. Robinson, 21/4/1932, UMA, FECC, Box 14.

115 Keynes to Copland, 19 May 1932, KPKG.

116 Occasional notes on Copland's visit to Cambridge, 26 May 1933 in BNSW: GM 302/412.

117 'Australia in the world crisis 1929-1933', 29 September 1934 in P.J. Grigg Papers 2/16/2e Churchill College, Cambridge. 
Gilbert, R. S. (1973) The Australian Loans Council in Federal Fiscal Adjustments, 1890-1965. (Canberra: ANU Press).

Goodwin, C. (1974) The Image of Australia (Durham, NC: Duke University Press).

Hancock, W. K. (1930) Australia. (London: Ernest Benn).

Hart, P. J. (1965) $f$ A Lyons and the 1931 Split. Unpublished manuscript. Department of History, Australian National University.

Hart, P. J. (1967) J.A. Lyons: a political biography. PhD Thesis, Australian National University.

Holder, R. F. (1970) Bank of New South Wales; a History, 2, 1894-1970 (Sydney: Angus and Robertson).

Howson, S., and Winch, D. (1977) The Economic Advisory Council 1930-39 (Cambridge: Cambridge University Press).

Hudson, W., and North, J., eds. (1980) 'My Dear P.M': R.G. Casey's Letters to S.M. Bruce (Canberra: Australian Government Printing Service).

Hytten, T. (1960) Giblin as an economist. In: D. B. Copland (ed) Giblin: The Scholar and the Man (Melbourne: Cheshire).

Love, P. (1983) Niemeyer's Australian diary and other English records of his mission. Historical Studies, 20, 261-277.

Malcolm, D. O. (1929) Australian loan policy. Australian Quarterly, 1, 11-20.

Mandle, W. F. (1978) 'Sir Otto Niemeyer: catalyst of Australia's depression debate'. In Going it Alone, Allen Lane, 73-79.

Markwell, D. J. (2000) Keynes and Australia. Research Discussion Paper 2000/04. (Sydney: Reserve Bank of Australia).

Melville, L. G. (1971) Review of C.B. Schedvin's Australia and the Great Depression. Australian fournal of Politics and History, 17, 144-145.

Richmond, W. H. (1971) S.M. Bruce and Australian Economic Policy 1923-9. Australian Economic History Review, 11, 238-257.

Robinson, W. S. (1967) If I remember rightly: The Memoirs of W. S. Robinson (edited by G. Blainey), (Melbourne: Cheshire).

Robertson, J. R. (1970) 'Scullin as Prime Minister: Seven critical decisions'. Labour history No. 17, June, 27-26.

Roe, M. (1995) Australia, Britain, and Migration, 1915-1940. (Cambridge: Cambridge University Press)

Schedvin, C. B. (1970) Australia and the Great Depression. (Sydney: Sydney University Press).

Selleck (2003) The Shop: a History of the University of Melbourne 1853-1939. (Melbourne: Melbourne University Press).

Shann, E. O. G. (1930) An Economic History of Australia. (Cambridge: CambridgeUniversity Press).

Shann, E. O. G., and Copland, D. B. (1931) The Crisis in Australian Finance 1929-31 Documents on Budgetary and Economic Policy. (Sydney: Angus and Robertson).

Spierings, J. (1989) 'As Exacting as Science: the University and the Beginnings of Economic Policy Making'. Arena No. 86, 122-135.

Tsokhas, K. (1989) Business, empire and the United Australia Party. Politics, 24, 39-52.

Tsokhas, K. (1990) People or money? Empire settlement and British Emigration to Australia 191934. Immigrants and Minorities, 9, 1-20.

Tsokhas, K. (1992) 'Coldly received': Australia and the London capital market in the 1930s. Australian Fournal of International Affairs, 46, 61-79.

Tsokhas, K. (1992) A pound of flesh: War debts and Anglo-Australian relations, 1919-32. Australian Fournal of Politics and History, 38, 12-26.

Tsokhas, K. (1994) Anglo-American economic entente and Australian financial diplomacy. Diplomacy and Statecraft, 5, 621-641.

Tsokhas, K. (1995) Sir Otto Niemeyer, the bankrupt state and the federal system. Australian fournal of Political Science, 30, 18-38.

White, G. (1992) Mastering Risk: Environment, Markets and Politics in Australian Economic History. (Oxford: University Press). 